\title{
Derrida's Democracy To Come
}

\author{
Matthias Fritsch
}

This is the pre-peer reviewed version of the following article: M. Fritsch, "Derrida's Democracy To Come" Constellations: An International Journal of Critical and Democratic Theory 9:4 (December 2002), 574-597, which has been published in final form at: http://www3.interscience.wiley.com/journal/118926048/abstract.

Abstract:

To assess the contribution of recent French thought to democratic theory, this paper discusses Derrida's 'democracy to come' in relation to a quasi-transcendental account of the constitution of meaning and identity in terms of an excess of time named the future to come. This reconceptualization of democracy cannot escape the affirmation of normative commitments, a commitment to futural openness that stands in need of justification. Derrida's intent to expose ineluctable aporias and contradictions of democratic decision-making disallows what Habermas calls a transcendental-pragmatic argument to the effect that we ought to be open to the future because the openness of the future is always necessarily presupposed by our symbolic practices. However, Derrida's insistence on unavoidable contradictions and aporias can provide a weak normativity if this insistence is viewed as aiming at the reduction of violence. I conclude by showing that Derrida tends to overreach the normativity he can justify, in particular in regard to the relatively neglected democratic values of economic and political equality.

Many commentators on democracy's recent crisis of legitimization agree that the modern processes of 'secularization' and 'disenchantment' have divested democracies of its traditional normative foundations that tied modern democracy to Enlightenment ideas of emancipation. The increasing recognition of contingency and the closure of the 'metaphysics of presence' have cast doubt on the centrality of the rational subject, on natural law and foundations of human rights, on ideas of progress, and so on. While some theorists seek either to abandon (Schumpeter, Downs) or re-found (Habermas, Rawls) democracy's normative footing, others affirm even those processes that have eroded it. They argue that secularization - due to its inherent suspicion of religious foundations, tradition, and the affirmation of a contingent and open future - should be 
seen as a chance for democracy, rather than as its demise. The loss of metaphysical foundations confirms the requirement of radical contingency - and, on a liberal view, the public neutrality with regard to questions of the good life - for democratic politics. ${ }^{1}$ Since democracy historically grew out of the dissolution of extra-politically fixed identities and interpretive models, increasing disenchantment offers political identity-formation and group-building, as well as the interpretation of basic democratic concepts (e.g., equality, liberty), up to the public discussion and rewriting among diverse and heterogeneous groups. In the resulting open field, the rational foundations which philosophy traditionally supplied as a (universal) force of unity are replaced by structures of a heterogeneous and open kind. It is precisely the ungrounded nature of democratic practices - the vacancy of the site of power, as Lefort put it- that makes them what they are. Secularization and disenchantment bring democracy into its own.

Jacques Derrida's recent forays into democratic thought might be seen as a prominent and sophisticated version of this approach. For Derrida not only affirms the absence of a pregiven (natural, theological, or transcendental-pragmatic, procedural) universality of norms that could support democracy. He suggests that the affirmation of a radically open future - a future that undermines metaphysical foundations - entails its own intrinsic normativity, a normativity that is helpful in reconceiving democracy. It is this claim that I will scrutinize here. Derrida argues that we can deconstruct the metaphysical, often rationalistic foundations of Western modernity while still holding on to the promises of the Enlightenment, one of which is the idea of democracy. Contrary to the liberal pragmatism of Rorty, however, Derrida does not consider the retention of the democratic promise a merely strategic, pragmatic decision among a range of alternatives; rather, he thinks we should avoid any empiricism and rethink the very nature of 
promising itself. In this way, secularization might not only represent a chance for democracy, but also point to its very condition of possibility.

Derrida indicates this argument in a phrase he has used frequently in his recent, more explicitly moral and political writings: democracy to come. In order to understand what $l a$ démocratie à venir - what Derrida calls "a democracy that must have the structure of a promise"2 - might mean, I will first turn briefly to Derrida's account of the temporal constitution of meaning and identity and what might be called the promise of repetition, a repetition from a structurally open-ended future. After this brief explication of the 'to-come' part of 'democracy to come,' I will then take up the relationship Derrida asserts between democracy and his understanding of time and its futurity. In section two, I will discuss three features that suggest a stong relation between democracy and the quasi-transcendental account of repetition from the future. I will show in section three that this relation cannot escape affirming certain normative commitments of democratic practices, and investigate the justification of the claim that we ought to be open to the future. In the fourth section, I will argue that Derrida's reformulation of democratic practices and their undeniable normativity cannot be argumentatively grounded in a quasi-transcendental account of the future to-come (the promise) without relying on the normative idea of the 'lesser violence.' Derrida cannot draw on what Habermas calls a transcendental-pragmatic argument to the effect that we ought to be open to the future and its otherness because the openness of the future is always necessarily presupposed in our identity and practices. Such an argument presupposes the prohibition of performative contradictions that are disallowed by Derrida's insistence on unavoidable contradictions and aporias. To try another route of justification, I consider in section five the consequentialist argument that openness to the future reduces violence and argue that this route, despite the many problems of defining and 
measuring violence, could provide an - albeit weak - normative link between democracy and an open-ended future. The last section reflects on uses of Derrida's notion of democracy that are in danger of overreaching its justified normativity, in particular in relation to capitalist markets.

\section{I}

What, then, is the structure of the promise that, according to Derrida, democracy must have? It might help to begin on the negative path and say what the structure of the promise is not. While the notion of democracy contains a number of specific, contentful promises - say, the promise of equal share in popular sovereignty, however this is understood - the structure of the promise here does not refer to any specific identifiable content. In other words, it is not a promise whose fulfillment at some future point in time can be expected, foreseen, or described. Democracy to come does not name a future democracy, nor is its promise ever embodied by an empirical political regime. The promise will always remain a promise. The 'always' here already indicates that we are no longer at the empirical level of promises made by identifiable subjects, but at an 'ontological' or, as Derrida prefers to call it, 'hauntological' or 'quasi-transcendental' level: we are talking about the "being-promise of a promise" [l'être-promesse d'une promesse]. ${ }^{3}$ This level puts into question the identity of a subject that would constitute a promise, or (according to Nietzsche) be constituted by its ability to make promises. Rather, the different senses of identity (the subject, content, and meaning of the promise) presupposed in empirical promising are looked at from the perspective of what makes them possible, a perspective that takes us beyond present identity and the homogenous chain of presents on which empirical promising seems to depend. 
For Derrida, identity (including the identity of a subject, of meaning, and of the present) is constituted in an open-ended process of repetition. This open-endedness indicates the relation to the future named in the phrase 'to come.' Insofar as the (minimal) identity accomplished by the process of repetition is never final but continuously requires renewed repetition to be what it is (or to be otherwise), it is deferred to a future that never arrives as such. As is well known, Derrida's neologism différance tries to capture this deferral of repetition as economically as possible, for it names both the movement of repetition in difference and that of deferral. The movement of repetition 'promises' the establishment of an identity that, however, is constantly undermined and referred again to repetition. Thus, no final and closed identity is ever accomplished by repetition. Repetition promises what it constitutes to a future that always defers its 'itself,' that never comes as such, in full presence, but only in the form of the provisional, minimal, and internally differentiated moments of an incomplete, fragile identity. The promise of repetition is (logically and temporally) prior to the identity that thus has to remain in process. For this reason, we can say that everything begins with a promise, a promise that never took place as such. This is what is meant by the 'being-promise of a promise,' for it spells out the quasitranscendental condition of possibility of empirical promising, by constituting the subject and the content it promises. As part of repetition that generates (and is prior to) subjectivity in the first place, the promise is directed toward the utterly indeterminable aspect of the future beyond horizons of expectation, planning, or awaiting.

Thus, for Derrida, the 'promise' of the future precedes us and yet opens the future. The alterity and non-presence of this future is such that it cannot be restricted to a particular domain of beings or appearances, nor can it be conceptualized. It is not a horizon of expectation or of determinate possibilities projected onto the future (such as a democratic utopia), but precisely 
names what I would call the blind spot in any horizon whereby it gives way to other horizons, other hopes and interpretations. Every interpretation of a history or a lineage, and thus every identity of meaning or of a constituted subject (e.g., of a nation), is projected onto the future. Since it may be criticized or revised by rival interpretations, the meaning of histories and traditions is always open to the future. This future is not beyond 'history,' but names precisely the infinite movement in which histories and identities constitute themselves. Keeping these structural features in mind - features that I do not wish to explicate or argue for here - let us look at what they imply for an understanding of democracy.

\section{II}

This structure of the promise, and the openness of the future it implies, form the background to Derrida's notion of the 'democracy to come.' The phrase suggests a link between democracy and the promise of a future to come, an unownable and unknowable future. What is this link? Derrida's explications of this notion lend themselves to two different (but not mutually exclusive) interpretations, a weak one and a strong one. On the weaker interpretation, the structure of the promise is viewed as underlying any concept, identity, or political structure, insofar as it is constituted by repetitions from the future: nothing specific about democracy would allow, or call for, the addition of the qualifier 'to come.' The stronger interpretation suggests that democracy, as a distinct political regime as much as a certain political experience, demands, more than other forms of political organization and practice, the exposure to an openended future indicated in the 'to come.' In what follows, I will concentrate on the stronger interpretation, as it is, I believe, the one Derrida has in mind. 
In Derrida's writing, I find three major features of democracy that suggest that democracy, in contradistinction to other political formations, practices, and experiences, demands its association with the deconstructive and quasi-transcendental theory of an open future. If democracy is to be thought, it must be thought as a democracy to come. All three of these features are distinctive of modern democracy, and may be linked to modernization processes. (This is significant, I think, because the - normative - affirmation of an open future may itself be viewed as inseparable from such processes. I will return to this below, if only briefly.)

(1) The first of these stronger links between democracy and the 'to come' comes when Derrida associates the idea of a democracy to come with infinite perfectibility, a perfectibility and infinity necessarily implied by 'democracy. ${ }^{4}$ The notion of infinity, of unavoidable incompletion, translates the (perhaps exclusively) democratic insight that no political principle or system, no law or universal ethics, can by itself be simply called just, precisely because of its universality and its place among the powers that be. For universality has to be applied to the singular that always, in the final analysis, eludes it. Furthermore, all institutionalized power owes itself to an ultimately unjustifiable instituting violence, a power that will always have had to exclude some in favor of others. ${ }^{5}$ Ultimately uncodifiable and without guarantee, justice, then, has to remain to come, against all desire for a good conscience. In other words, justice has to be what I would call a post-utopian promise that will never be fulfilled as such. This line of reasoning forms the thrust of Derrida's critique of Fukuyama's claim that Western liberalism has become the sole incarnation of justice as the 'end of history' after the breakdown of the Soviet Union. ${ }^{6}$ Justice, in its link to uncodifiable and uninstitutionalizable singularity, can neither be 
fully captured by empirical reality, nor by a political ideal, the two poles between which Fukuyama wavers. Rather, justice must be tied to a necessary disadequation between ideal and reality, for it is in the space between them that opportunities for perfectibility open up.

According to Derrida's argument, democracy to come indicates that democracy harbors this promise of infinite perfectibility, the promise to perfect it and go on criticizing its instituted form:

This doesn't mean that 'democracy to come' will be simply a future democracy correcting or improving the actual conditions of the so-called democracies, it means first of all that this democracy we dream of is linked in its concept to a promise. The idea of a promise is inscribed in the idea of a democracy: equality, freedom, freedom of speech, freedom of the press - all these things are inscribed as promises within democracy. Democracy is a promise. That is why it is a more historical concept of the political - it's the only concept of a regime or a political organization in which history, that is the endless process of improvement and perfectibility, is inscribed in the concept. So it's a historical concept through and through, and that is why I call it 'to-come.'?

Here then, democracy as a regime or a political formation (but perhaps also as an experience) is linked to the promise of repetition. The link is achieved by the notion of history, and seems to rely on modern forms of historical consciousness: as opposed to other political formations, democracy is aware of its perfectibility (and, we would have to add, the possibilities of its degeneration) in history, thus opening and exposing itself to the messianic future. In this way, democracy admits its constitutive incompleteness, the deferral of full presence to a future that remains to come forever, and thus its historicity (which, as I indicated above, is constituted by the exposure to repetition from the future). In other words, the future to come indicates that all sedimented institutions and political relations owe themselves to historical decisions (rather than to natural frontiers) and thus may be returned to their undecidability. In the Politics of 
Friendship, Derrida refines this thought by arguing that democracy harbors in itself the selfdeconstructive force characterized by the messianic promise: "no deconstruction without democracy, no democracy without deconstruction.... Democracy is the autos of deconstructive self-delimitation. ${ }^{\prime 8}$ We may translate this by saying that democracy needs the self-deconstruction of its most basic concepts and institutions (so that democratic societies remain open to challenge and perfection), while deconstruction, as a textual operation, needs the democratic rights "to the question, to criticism, to deconstruction."

(2) With this mention of the institutionally guaranteed right to free speech, we have moved on to the second, distinctively futural feature of democracy. Derrida points out that if one criticizes democracy - for example, for its traditional exclusion of the 'sister' from its fraternal order, for its distinction between the natural-born member and the outsider, for its law of filiation - one does so in the name of democracy, in the name of a democracy to come. ${ }^{10}$ Even if one criticizes democracy itself, one is authorized to do so (and thus already encompassed) by democracy. For democracy, by granting the right to free speech, free assembly, and a free press, is the form of political organization that calls for its own critique and that admits the fundamental revisability, and openness to challenge, of its own self-understanding. With this admission, democracy opens up a space between its actual condition and its future space - which may or may not be a regulative ideal ${ }^{11}$ - and situates itself between the present present and the future present, between presence and the messianic, absolute future. It is this space, this u-topic space between the present and the future, that la démocratie à venir delineates, by opening up a space in which the definition of the ideal, and of the meaning of such fundamental terms as freedom and equality, remains open-ended. 
This democratic and atopical (non-present) space may also be viewed as a polemical space. The promise of repetition, and the open-endedness of the future to come, keeps the values and institutional structures open to different interpretations of what democracy means, thus allowing multiple voices to clash and negotiate with one another. The thinking of the messianic or absolute future could thus support the space or field in which this polemos, this clash, is to take place. It might serve as a reminder that the other, and the other others, be heard, both from within oneself and from the outside. The 'to come' would put a question mark behind everything put forward under the heading of 'democracy' - for instance, by referring to allegedly 'natural' and hence unquestionable rights. Further, it might help to prevent the ossification of interpreted values and the closing of possibilities: the supreme democratic virtue would be to question oneself before questioning others. (The messianic future is opposed to liberal good conscience.) But the messianic future, on Derrida's view, would also keep democratic structures, such as equality and the always universal law, open to an appeal from singularity, interrupting the universal-juridical framework to let the justice of singularity come forth. In this way, democracy would be enabled to face and thus negotiate its inescapable aporias, first and foremost hospitality and openness to the singular other and the equality of all. (We will return to the question of aporia in a moment.)

For purposes of clarification, this deconstructive space of discourse may be compared to Habermas's understanding of the requirements of democratic discourse. On Derrida's view, the polemical space of democratic decision-making is opposed to a notion of deliberative democracy that specifies normative procedural criteria in advance. In the name of intelligibility and common sense, Derrida fears, a homogenous medium, a universal model of language, may be superimposed on the radically open forms of democratic discussion and questioning. Thus, the 
polemical open-endedness of discussion may be construed as a deconstructive rejoinder to a discourse-ethical account of democratic deliberation: it would be a democratic discourse governed by openness, infinity, and the possibility of unsurpassable dissension that requires compromise rather than by normative rules given as universal and geared toward transparency and consensus. ${ }^{12}$ In addition, Derrida claims - perhaps a bit hastily - that discursive norms program decisions, neutralize the event as the arrival of singularity, paralyze much-needed inventiveness, and thereby rule out responsibility as the relation to the otherness of the other. ${ }^{13}$

(3) The open-endedness of discussion, however, also implicates the subjects engaged in such political discussion, for their identities are as much exposed to the radical futurity of time as are the topics of discussion. With this insight, we have moved on to what I would isolate as the third feature permitting a strong link between democracy and this futurity. Apart from historicity, perfectibility, and the 'freedom to say anything and everything' linking democracy and the to come, we must also take account of the symbolic space of (specifically) modern democracy. Given the theory of repetition from the open future, and the resulting relationality, openendedness, instability, and lack of arché and telos of any identity, the link between selfdeconstruction (and its temporality) and democracy can also be described by focusing on the constitutive and admitted openness of the democratic political field, as opposed to pre-modern forms of social organization that relied on references to extra-political instances to ground and center the political order. ${ }^{14}$ This might also connect democracy to come with the basic democratic idea of popular sovereignty. The sovereign's identity - that is, the identity of 'the people' - is not fixed, and in principle (at least) cannot be determined other than by the interpretations and continuous re-identifications of the people themselves. Democratic unity and 
sovereignty are thus inherently unstable, internally and infinitely differentiated, and open to never-ending contestation. In other words, democracy opens itself by itself to the infinite repetition from the future: democracy is always a democracy to come. A turn to the open future as democracy's own implication, and the resulting recognition of the contingency and instability of a nation and its borders, would imply an originary dislocation of the 'natural' community, the native place, and the nation-state. This regard for ineluctable futural openness ushers in a politics of hospitality, a rethinking of immigration policies and citizenship. ${ }^{15}$

\section{III}

Having shown the ways in which modern democracy may be connected to Derrida's understanding of the radical futurity of time, let me now investigate the normative dimension of the relation between democracy and the 'to come.' Since 'democracy to come' links a political concept - whose assertion or defense implies a number of normative commitments - to a quasitranscendental or quasi-ontological one, we must ask what these normative commitments are, and whether they are grounded in, or supported by, the arguments regarding the inescapability of a structural opening. It is noticeable, of course, that both the quasi-transcendental and the normative-political are concerned with futural openness. Given this structural homology, one might think that traditional demarcations between fact and value do not apply here. The swiftness with which Derrida at times (see below) moves from what used to be called an 'ontological' to a 'normative' claim might indeed be taken to indicate that he does not recognize a fundamental distinction here, and it is certainly true that deconstruction has delimited the pertinence of the classical distinction and hierarchy between ontology and epistemology, on the one hand, and ethics and politics, on the other. ${ }^{16}$ Furthermore, we might say that in the absence 
of non-inherited normative criteria, political interventions can only be justified strategically. And above, we have seen that the quasi-transcendental understanding of the promise of repetition, and the concomitant notion of an absolute or messianic future, imply the historicity of politics, that is, its inescapable inscription in inherited discourses. In explicating the strong link between democracy and this future, we elaborated this inscription further in terms of the nongroundedness of democratic identities and institutions. In this sense, it is not only the case that deconstruction does not attempt to ground democracy in extra-political, non-inherited norms, but that the qualifier 'to come' renders untenable any such derivation or grounding and the ahistorical legitimization that it has traditionally implied.

So Derrida might be taken to claim only that, if subjects in the Western states are committed to democracy - a concept and a practice we have inherited, and so can only, as with any heritage, "reaffirm by choosing" different strains and interpretations of its tradition ${ }^{17}$-we should be aware that this affirmation and choosing are necessarily undertaken as a differential repetition from an open future. On this view, the normative commitments of democratic practice are simply implied by - and by no means necessarily follow from - a certain given historical situatedness in the West, whereas the affirmation of the open future is implied in the unavoidable practice of filtering through the historical situation. This view of the relation between the quasitranscendental and the normative levels coincides with what I called a weak interpretation of the link between democracy and the future to come.

If my demonstration that Derrida affirms a stronger link is correct, however, it should be clear that the unavoidable practice of inheriting from an open future has some close affinities with what is inherited in this case, namely, democracy. This seems to single out democracy as more attuned to the work of inheritance by way of repetition from the future. It seems undeniable 
that Derrida's reformulation of democracy does not affirm just any form of political organization, and not even just any strains and interpretations of the democratic heritage. For example, Derrida's democracy to come appears much less defined by popular sovereignty, equality, and majority rule - although Derrida recognizes their importance ${ }^{18}-$ than by free speech, openness to criticism and otherness, and hospitality to singularity. This shows, then, that Derrida's concept of democracy selectively inherits and reformulates those features that show a structural homology between the normative and the quasi-transcendental levels, and that are cut to fit the deconstructive understanding of identity-formation, of time and space, and so on. In this way, Derrida is led not only to the unavoidable affirmation of historicity and futural openness an affirmation which he says is affirmation itself ${ }^{19}$ - but to affirm a certain type of democracy involving the commitment to free speech, to hearing the other out, to being open to challenges regarding the interpretation of essential concepts, to criticize and perfect institutions with a view toward singularity and otherness, etc., in short, to what Derrida routinely affirms as his gloss on the emancipatory project of the Enlightenment. ${ }^{20}$ And these more specific, undoubtedly normative affirmations seem neither to be analytically contained in concepts of 'democracy' - so that a commitment to democracy necessarily implies a commitment to them - nor do they, in any obvious way, follow from the promise of repetition.

It should come as no surprise, then, that Derrida is quite willing to use the normative language of 'ought' and 'duty' in his discussion of messianic and democratic experience. The normative commitments that are involved in Derrida's reconceptualization of democracy in terms of infinite perfectibility, free speech, and the non-groundedness of the symbolic space of democratic identity-formation, are epitomized by what he calls a "categorical imperative" of the event or of experience. ${ }^{21}$ Derrida says: 
The happening of the event is what cannot and should not be prevented: it is another name for the future itself. Not that it is good - good in itself - that everything or anything should happen; nor that we should give up trying to prevent certain things from coming to pass (in that case there would be no choice, no responsibility, no ethics or politics). But you do not try to oppose events unless you think they shut off the future, or carry a threat of death.... ${ }^{22}$

Notice how Derrida moves from the structural impossibility of closure ('cannot be prevented') to the normative claim that such closure ought not be prevented. In the face of this move, and given the structural homology of the ontological (better: quasi-transcendental) and the normative, political level, we must wonder how we are to understand their relation. Derrida at times seems to suggest a rather strong relationship, as in the above passage (which suggests that what cannot be avoided must not be avoided). Even if we do not expect any unquestionable foundations for values, or any rational necessity to lead from a quasi-transcendental account to moral and political affirmations, it seems fair to ask why a normative call to openness to the event, and everything that implies for democratic practice, should be linked to, or even follow from, the ineluctable exposure of any identity and meaning to a structurally open-ended repetition from the future.

\section{IV}

To my knowledge, Derrida nowhere presents an argument for why we ought to be open to the future to come in any detail. However, in a quasi-transcendental fashion (whose 'quasi' would have to be carefully explicated), Derrida does argue that openness to the future is the condition of possibility of the event, of identity, of decision, responsibility, hospitality, and in general the relation to the other, concepts that make up the normative commitments of democracy to come. The identity of a responsible subject, as well as the event of decision, is established only by way 
of a productive and differential repetition from an open-ended future. This future in turn installs an originary otherness, a certain undecidability, in the very fabric of identity and the event. Every 'subject' and every moment in time has always already been opened to the other (that is, to otherness in general, as manifested, for instance, by personal others). So the event of decision as well as agency and identity are not possible without the absolute futurity of time. It is both the condition of possibility as well as the condition of impossibility, of the conditioned in its metaphysical or traditional purity: while it makes the presence of subjectivity and of every moment in time possible, it also introduces an originary otherness that renders this presence unstable and compromised, shot through with an absence that, Derrida claims with Heidegger, the Western tradition, including the tradition of political thought, forgot to think.

Relying on this account, one could try to utilize an argument whose formal structure is used frequently today in ethical and political contexts: from Martha Nussbaum's resuscitation of Aristotle's argument that human beings are social beings, to Alan Gewirth's claim that human action presupposes a conception of oneself as free, and, of course, to Jürgen Habermas's and Karl-Otto Apel's transcendental pragmatics of language. ${ }^{23}$ This formal structure may be represented as follows: if doing (x) presupposes or is made possible by (y), everyone doing (x) must be committed to affirm (y). In Derrida, this structure would be filled with the following content: given that futural openness makes every identity and decision possible, and is thus presupposed in the very effort to close it, an attempt (always doomed to failure) to forego, neglect, or close off this future involves a (performative) self-contradiction. Therefore, we ought to affirm that which makes our identity, subjectivity, and agency possible. Assuming for the moment that the notions of 'presupposition' or of 'making possible' - the question of quasi- 
transcendentality - as well as of 'commitment' could be fleshed out satisfactorily, this argument still requires for its validity the value of the logic of contradiction.

However, it is very doubtful that deconstruction could avail itself of this type of argument championed by Habermas and, above all, by Apel. For, to cover a lot of ground very quickly, Derrida and others have deconstructed precisely the idea of a subject that would be so sovereign to language that it could be held responsible for its effects. ${ }^{24}$ And one of the effects of language is precisely that it makes contradictions inevitable. That is why one of Derrida's most central proposals in the area of ethical and political ideas is the inevitability of aporias, paradoxes, and contradictions, an insight that leads Derrida to claim an 'originary violence' as part and parcel of the condition of human finitude. More to the point of democracy, Derrida emphasizes that the experience of aporias and contradictions (of what he calls the 'impossible' or undecidability) is inescapable in every decision that is not merely 'programmed.' The reason for the inescapability of this aporia lies in the quasi-transcendental conditions of identity themselves, for they are, as I indicated a moment ago, also conditions of impossibility. The establishment of identity requires the repetition of the same, but repetition can only be repetition in difference, or repetition from an open future. ${ }^{25}$ While this future is entirely indeterminate, by way of repetition it inserts us into specific contexts that project determinate horizons of the future. According to this argument, then, we cannot not project horizons that close the future, but we also cannot avoid the fundamental weakness and instability of such horizons, that is, their necessary non-closure. To establish identity, we need to project future horizons of meaning and repeat what we have inherited, but such repetition, in the same movement, opens up the horizons to the absolute future. In other words, repetition from the open future makes identity possible, but also again and again undermines it. 
Following Levinas's notion of the other as present and absent at the same time - a (non)phenomenon that, Derrida noted as early as 1964 , contests the logic of non-contradiction ${ }^{26}$ Derrida has demonstrated the inevitability of contradictions in several ethical and political concepts, which then have to be complicated in order to allow us to take this radical otherness into account. Perhaps this demonstration is most accessible in the notion of hospitality, a notion embodying the normative commitments of democracy to come. ${ }^{27}$ In the same way that the relation to the future demands both horizons of awaiting and the openness beyond all such horizons (i.e., the future to come), the ethical relation to the other requires both limits of acceptability and a limitless openness. Derrida describes this contradictory injunction as the reciprocal co-determination and co-implication of conditional and unconditional hospitality. If hospitality means openness to the other as other, the imposition of conditions for her or his acceptance - including the demand that the other be identifiable, give his or her name, and speak the language of the host - seems to compromise the hyperbolic demand for unconditional hospitality and inflict a certain kind of violence on the other. On the other hand, such violence is unavoidable, for without conditions of hospitality, there is no reciprocity and equality between host and guest, ${ }^{28}$ the other cannot be granted the equal legal rights of all guests or foreigners, and hospitality cannot be institutionalized and translated into a "concrete politics and ethics" as demanded, for example, by democracy's infinite perfectibility. ${ }^{29}$ Furthermore, hospitality presupposes sovereignty and power over a house or home - a power and a "law of private property ${ }^{\prime 30}$ whose institution, that is, whose initial introduction and maintenance, can hardly be thought without some degree of violence. This power is itself violent in having to exclude some potential guests in favor of others, but its granting of unconditional hospitality to all would also undermine itself, partly because the guest may always turn out to be a parasite. ${ }^{31}$ Thus, 
unconditional hospitality calls for conditions, and conditional hospitality, to be true to its meaning and avoid the rigidification of a good conscience, calls for unconditional hospitality. ${ }^{32}$ These and similar considerations lead Derrida to conclude that an "ethics of hospitality" is "limited and contradictory a priori. ${ }^{, 33}$ In other texts, Derrida extends this claim to all obligations and injunctions, claiming that they are always contradictory and inevitably lead us into a double bind. $^{34}$

As the case of hospitality shows, a significant part of Derrida's contribution to ethical and political thought consists of insights into unavoidable contradictions besetting its concepts and injunctions. What, then, are the inevitable contradictions of democracy, the ones that are to be brought to the fore by the concept of 'democracy to come'? Where is the ineluctable alternation between future horizons and their openness and undecidability, an aporetic alternation that remains forever to be negotiated? The first aporia Derrida mentions is a transfer of hospitality to the 'people': democracy, Derrida claims, requires the definition of members and territory, and hence borders, but also requires hospitality to the foreigner. ${ }^{35}$ The second aporia again concerns the notions of equality and singularity. When making democratic decisions we cannot avoid affirming the equality (and hence, to some degree, the sameness) of all juridical subjects, while at the same time concerning ourselves with the singularity of each. ${ }^{36}$ Thirdly, we must calculate majorities in a democracy (unless we suppose that deliberation brings about unanimous consensus), but majority rule always threatens minorities and their rights - the uneasy alliance of democracy and liberalism. ${ }^{37}$ In the face of these aporias, the point for Derrida is not to avoid contradiction, but to experience the aporia in order to invent a new rule each time: openness to the future implies decision and invention. All sedimented institutional structures and social 
relations are exposed to an open future that recovers their contingency, the moment of decision, and their democratic negotiability.

As this discussion shows, by foregrounding ineluctable contradictions, deconstruction cannot - and perhaps Derrida never intended to - argue that we ought to affirm openness because it is presupposed in our own identity. Since Derrida shows that these presuppositions are themselves - and necessarily, at a quasi-transcendental, 'a priori' level - at odds with one another, the subject cannot be held responsible for, and be asked to avoid, their contradiction. Normative openness is thus intrinsically connected to inevitable self-contradictions, and part of the poignancy of insisting on it is to emphasize the necessity of negotiating the contradictory injunctions, the aporetic openness, the relation of identity and difference. My point here is that even if we grant that all particular affirmations, all particular promises with definite content, and all performativity have always already affirmed the differential repetition from the future to come that makes them possible ${ }^{38}$ - in the same way that all questioning has always already affirmed language and the workings of différance, as Derrida argues with Heidegger ${ }^{39}$ - this still does not mean that we ought to be open to the future to come. Unless we mean not that we ought to welcome the other and the future unconditionally, but only that we ought to recognize and be aware of aporias, and it is this latter idea that I will now explore further.

\section{V}

Despite the failure to justify futural openness normatively, uncovering inevitable contradictions in ethical and political decisions and institutions seems to be a pragmatically useful insight, one that has been put to work in largely non-normative analyses of democratic practices. ${ }^{40}$ So even if Derrida's arguments for normative openness failed - and we will consider another attempt at 
justification momentarily - democracy to come could still be a politically important and revealing category. It would be incumbent upon deconstruction to show that the rewriting of democracy as democracy to come can help us tackle issues that democracy faces today. And Derrida has certainly tried to show the usefulness of a deconstructive understanding of time and space to contemporary political changes. Among these challenges, we could name the virtualization of power and identity by new tele- and media-technologies and the concomitant erosion of the link between power and space; the internationalization of politics and the questioning of all natural and national borders the necessary excess, non-totalizability, or constitutive outside of every democratic community ${ }^{41}$; and, of course, the proper interpretation and response to the waning of the metaphysical foundations of democracy, and the resulting emptiness of its site of power. In regard to such problems, deconstruction could yield a revealing analysis. Furthermore, uncovering the aporias affecting democratic decision-making could alert us to unavoidable contradictions and thus help us to avoid possible pitfalls. This latter thought returns us to the question of whether normative openness can be justified after all.

If Derrida's uncovering of inherent contradictions and originary violence at the heart of the human condition rules out normative recourse to the notion of performative contradiction, it may also suggests a way out. For the point of insisting on aporias and (not primarily physical but 'originary') violence is not a postmodern pleasure in paradoxes, or, even worse, a gay and irresponsible nihilism. Rather, the point is to complicate ethical life beyond the (always too quick) demands of good conscience, to demand that one question oneself while or before questioning others, to insist on the tragic dimension of political life and the need to negotiate ultimately irreconcilable obligations. ${ }^{42}$ Thus, in an effort to defend Derrida's normative claims, we could consider the political analysis in terms of the promise, différance, iterability, etc., as 
outlining an ethics and a politics of what Derrida, in "Violence and Metaphysics," called the "lesser violence." ${ }^{43}$ The difficulties of first defining and then measuring violence are, of course, enormous, especially in light of Derrida's account of originary violence, and the aporia of undecidability. Provided these difficulties could somehow be met, and further presupposing that unnecessary violence is to be avoided, the attempt to close horizons of the future - that is, to establish a political identity devoid of the need for a repetition from the future and, thus, political (democratic and open-ended) negotiation - could be shown to be needlessly violent, given that identity and future horizons cannot ever be closed. The passage from a quasi-transcendental account to normative claims would then consist in the idea that we ought to refrain from trying to do what is quasi-transcendentally impossible (e.g., a closed political field, identity without relation to otherness), for the attempt to accomplish the impossible would produce "absolute evil" or the worst violence. ${ }^{44}$ In other words, quasi-transcendental impossibilities only call for their recognition in view of a politics of the lesser violence.

I cannot be certain that Derrida would subscribe to this argument, though it has been advanced, and attributed to Derrida, by some of his commentators, ${ }^{45}$ and can be reconstructed from several Derridean passages. We should not underestimate the difficulties of this consequentialist ${ }^{46}$ argument, nor should we be mistaken about its scope, about what it can and cannot justify. While it can justify the call for a recognition of originary violence, aporias, and contradictions - aporias that result precisely from openness at the quasi-transcendental level - in order to help reduce violence and invent a new relation to the singular situation, it cannot, I believe, justify the normative claim that this reduction of violence is, in all contexts, achieved by unconditional hospitality and openness to the future to come. Such a claim cannot be decided universally in theory, as Derrida appears to suggest when he names unconditional hospitality a 
"regulative idea." ${ }^{47}$ Let me explain why a universal openness to the future to come and to the personal other does not follow, and why we ought to distinguish here between this normative openness, and justifiable openness as an awareness or recognition of aporias.

According to the second argument, it seems, openness to the future and to the other is normatively required because it reduces violence in all contexts. However, both structural considerations regarding futural openness as well as unconditional hospitality, and pragmatic considerations regarding the singularity of the situation lead us to doubt this universality. Not only conditions placed on the other, but also unconditional hospitality can lead to unavoidable violence in breaking with conditional and juridicalized hospitality, and in its tendency to undermine itself. For this reason, it is doubtful that the (quasi-transcendentally necessary) openness that characterizes subjectivities and the political field can give rise to the Kantian 'regulative idea' of unconditional hospitality, and that this idea can universally orient, in what Derrida calls a "progressive movement," the conditions and limits placed on openness to the other ${ }^{48}$ If 'progress' means, in line with this interpretation, the reduction of violence, it cannot be guaranteed in advance for all contexts that the violence resulting from unconditional hospitality is less than the one resulting from conditional hospitality, laws, institutions, rights, and so on. As Derrida indicates at times, the lesser violence can largely be determined only after the fact, après coup, after an institution has been inaugurated or a decision made. This uncertainty follows precisely from the ineluctable openness and incalculability of the future on which he insists: it is obviously paradoxical to suggest openness to the future beyond expectation as a norm on the basis of the calculation of the future effects of an action. As Derrida himself admits, whether deconstructive affirmation of the future to come 'succeeds' "could never be the object of knowledge or of certainty." ${ }^{49}$ Such inescapable affirmation may, then, strive to be open 
to the future in the sense of being attuned to the singular situation and its aporetic demands:

"Every action and every political decision ought to invent its norm or its rule." ${ }^{, 50}$ This invention may aim at the reduction of violence, but it cannot be asked to always aim at unconditional hospitality and openness to the other and to the future in the normative sense.

Geoffrey Bennington, who has advanced this second interpretation of Derrida's ethics although he also appears to maintain what I have analyzed as the argument from noncontradiction - has recognized this paradox, but still thinks it possible to hold on to "something like the categorical imperative in terms of a "lesser violence in an economy of violence." ${ }^{, 51}$ Due to this paradox, Derrida is more consistent when he claims that the aporias and "internal contradictions" besetting unconditional hospitality render its regulative idea inaccessible not only for empirical, but for structural reasons. ${ }^{52}$ Thus, we should draw a conclusion Derrida does not appear to draw: openness to the other and to the future cannot be stipulated as a normative, regulative idea with universal reach. If invention is to be truly inventive and attuned to singularity, it cannot be limited in advance by a regulative idea, even if the regulative idea is precisely the idea of unconditional openness. For the idea of giving a criterion for the absence or relative lack of criteria is not only paradoxical, it limits the possibility of choice. Rather, political invention must be open to decide against openness: surely, there are singular situations where openness to the other is inadvisable, where a reduction of violence is to be expected not from unconditional hospitality but from (further) conditions, demands, and normative expectations placed on the other, and where political planning, as the projection of horizons, advances democratic hopes - even if such expectations and horizons must, for structural as well as normative reasons, themselves remain subject to repetition from the future to come. 
If the insistence on aporia cast doubt on the first, transcendental-pragmatic argument, it decreases the reach of the second, consequentialist argument for la moindre violence. It forces us to make a distinction between the awareness of aporias - for only such awareness gives us the chance to reduce violence - and the response to such an awareness, namely, unconditional hospitality to the other and a welcome extended to the pluralizing, differentializing work of the repetition from the future. That the ineluctable work of differential repetition casts us into aporias that we ought to recognize in view of the lesser violence does not, I believe, amount to an ethics of openness to the future to come and to the personal other, unless all we mean by normative openness is a disposition that allows us to recognize these aporias. It might be the case in some singular situations that openness to the future and unconditional hospitality generate the least violence, but it is not very difficult, as Derrida appears to recognize, to imagine situations in which this openness would tend to produce greater violence. Hence, we may be called upon to be so open as to recognize an ethico-political impasse and avoid neglecting the conflicting ethical demands of, say, care and equal justice (to use Gilligan's terms), or an unconditional gift to the other and the demands of the third party (to use Levinas's terms), but whether the violencereducing response to such recognition will lie on the side of unconditional hospitality can only be decided from within the situation.

All this goes to show, I think, that thinking of ethics and politics in terms of aporia, and insisting on singularity, may be useful and even necessary, but they also disallow universal normative recommendations on their own terms. Derrida may argue, however, that the absence of an opening, the contentment with existing conditions and institutions, and the failure to recognize ineluctable aporias, can, and often does, lead to a violence that can be reduced by the ethical demand for unconditional hospitality and openness to the future. Given the (quasi- 
transcendental) impossibility of closing political identities and structures once and for all, the attempt to do so may be expected to generate unnecessary violence. The ethical call cannot be that we must keep institutions and democratic political structures open on pain of their ultimate closure, for such ultimate closure is as little possible, according to the quasi-transcendental argument, as complete openness. Rather, the call only attempts to bring to our awareness this space of aporetic negotiability, and reactivates the democratic possibilities at the heart of all frontiers, politically relevant distinctions, and sedimented structures. If we presuppose that in an economy of originary violence, violence is to be reduced, Derrida can legitimately argue that this democratic space of contestation as well as of invention is normatively demanded. The Derridian concept of democracy to come calls for the back and forth, the undecidability that often only results if we experience or admit the hyperbolic call to absolute openness and unconditional hospitality to the singular other.

So there is a modicum of a normative link between 'democracy' and the 'to come. ${ }^{53}$ Derrida's argument, as reconstructed here, is that openness to the future and to the other reduces violence in preventing that which the quasi-transcendental account revealed as impossible (such as the closure of political structures, ahistorical norms, and the like). Such openness is best exhibited by a reformulated version of an inherited form of political organization and experience, to wit, a democracy that emphasizes free speech and openness to criticism without unquestionable foundations or extra-political ('natural') norms, openness to the plurality of identity-formation, and the awareness of ineluctable aporias. The future to come introduces into democratic organization the post-humanist insight that, despite the absence of extra-political (theological or natural) instances and non-inherited moral standards guaranteeing order, the political cannot be reduced to, or exhausted by, the merely human. Since all political 
organization and institutionalization is marked by an excess of time, by a constitutive outside or remainder, by a radical otherness Derrida has named the messianic promise, we ought not to attempt to a closure or reduction that might be expected to produce unnecessary violence. ${ }^{54}$

\section{VII}

To conclude, I would like to use the 'example' of democracy's relation to 'free' markets to express my concern that a normatively distinguished futural openness might be misunderstood so that it may be taken to justify capitalist markets. Such a justification, I believe, would be unwarranted. When it comes to the relation between democracy and the capitalist market, Derrida at times advocates state intervention and regulation, and at other times affirms the openness, pluralization, and flexibility of production and consumption markets allegedly bring. ${ }^{55}$ In order to prevent closure of the socio-political field, in this case by economic accumulation of capital and power, and in order to keep multiplying democratic possibilities, Derrida advocates state intervention in, and regulation of, markets. At the same time, however, he argues that the logic of the state might fall into nationalism, protectionism, and an over-regulation of the market that would in turn (unnecessarily) limit the possibilities of the future. So the task, as Derrida sees it, is not only to be open to the future and multiply its possibilities, but to understand that no rule (e.g., for or against state regulation) will tell us in advance what course of action opens the future, and that openness to the future requires the ordeal of undecidability and the invention of new rules.

While Derrida thus leaves it up to the particular situation to determine which course of action is best, what is best is here determined in terms of the openness to the future to come, what Derrida calls, in this context, a "categorical imperative" that asks us "to leave the future to 
the future [laisser de l'avenir à l'avenir]... to leave open the possibility of the future and, therefore, to negotiate between rhythms so that, at the very least, this opening is not saturated." Here, the normatively desirable outcome is not determined with regard to a reduction of violence, but with regard to the open future to come. In the discussion of capitalist markets, insisting upon openness to the future might be taken to justify the wide-spread economic insecurity which, as a result of neo-liberal policies and so-called 'globalization,' affects so many today. ${ }^{57}$ Of course, we may try to oppose, with Derrida, the deconstructive insistence upon an indeterminable and incalculable future to the future calculations of profitability required by economic exchange and investment. However, the overall result of many 'private' calculations, as Marx demonstrated, is an overall incalculability of market effects, leading to largely unforeseeable economic crises on the micro- as well as the macro-levels. To avoid the implication that a quasi-transcendental as well as normative affirmation of futural openness welcomes the, on principle, avoidable economic insecurities of capitalist markets, it is necessary to insist that such openness can be normatively distinguished only in the sense of an aporetic space of invention that affords us the chance to reduce violence. In this context, it would be more important to reveal the aporetic relation between markets and democracy, rather than to underline that the market is not the enemy of democracy ${ }^{58}$ The recognition of aporias in view of the lesser violence might lead us to a sharper understanding of the conflict between economic exigencies and political democracy, between equality and freedom, but it would not necessarily affirm markets in line with futural openness, precisely because markets may generate greater violence. While the dangers of normalization and social uniformity need to be recognized in favoring greater economic equality, a reduction of violence might, in many cases, precisely result from the latter as well as from greater economic security and stable political institutions. 
Derrida may relate the two different goals - reduction of violence and futural openness by arguing that worse violence would be generated by the attempt to close the future, an argument that, as I have indicated, may be acceptable provided we can define the elusive term 'violence' sufficiently for given contexts. But it does not follow that openness can be normatively distinguished as an intrinsic goal in the sense of, say, the dissemination on which deconstruction insists. If the aporias of democracy, and more generally of ethical and political life, demand a space for the inventiveness of possible responses to such aporias, such inventiveness in turn calls for the leeway of democratic negotiability, but it does not seem to require a positive valuation of economic uncertainties, or the flexibility of production and consumption allegedly afforded by capitalist markets. Surely, as Derrida argues against Marx's call for the "end of the political" that would also be an "end of the spectral" and of futural otherness,${ }^{59}$ the abolition of 'free' markets in favor of state planning may be inspired by a political imaginary that neglects the ineradicable internal differentiations and alterity of 'the people' or 'the proletariat' brought about by repetition from the future to come and the nonclosure it introduces into such concepts. However, whether state planning of the economy, for example, leads to a greater violence than the economic insecurity, inequality, and curtailment of freedom the markets require, would have to remain an open question.

Derrida's democracy to come, then, is still insufficiently theorized and balanced to take account of (the limits of) its own normativity, especially in regard to the indispensable value of democratic equality as it conditions freedom, popular sovereignty, as well as the pluralization of creative possibilities for responsive action, as favored by Derrida. ${ }^{60}$ Even if we prize pluralization above all, both economic and political equality may be said to contribute, to a considerable extent, to its flourishing. As Foucault has demonstrated, the deployment of 
normalizing disciplines was (and is) needed in part to support the perpetual economic 'growth' of the market and to sustain its inequalities. And further, the large inequalities 'free' markets, in their current form, bring also generate competitiveness, disaffection, intolerance, and social violence, perhaps especially - or more recognizably (a problem of unequal access to mainstream media) - on the part of the dispossessed and downtrodden. This drives the spiral of violence in the direction of more disciplinary power in democratic institutions, especially more prisons, as William Connolly, for one, has shown. ${ }^{61}$ However, both Connolly and Derrida seem to value equality and economic equalization only to the extent that it allows more 'critical responsiveness' or 'agonistic respect' (in Connolly's terms) or 'openness' and 'hospitality' (in Derrida's terms), not as a value in itself. Not only is such openness in danger of neglecting one of the at least nominally constitutive features of the concepts of democracy we have inherited, but its normativity remains difficult to justify, in Connolly as much as in Derrida. ${ }^{62}$

I think such problems - the lack of an account of equality and its value, the difficulty of justifying normative openness to the future to come, the weakness of its connection with democracy on the basis of the reduction of violence alone - indicate the precariousness of attempts to affirm and reconceive democracy without engaging, at the conceptual level, the normativity of freedom, equality, popular sovereignty, community, and individual rights, values that have historically been sedimented in democratic institutions. The difficulties might thus stem from a selective reinterpretation that affirms the condition of inheritance of these values, and sees them primarily in the light of their futurally open-ended historicity. These difficulties might be met, for instance - as Bernard Stiegler and Richard Beardsworth have pointed out in different contexts ${ }^{63}$ - by a more genealogical perspective that accounts for these values and explicates the asserted link, including its normative dimension, between democracy and radical 
futurity, thereby supplementing the primarily conceptual operation we find in Derrida's writings. If we do not understand futural openness as valuing what Walter Benjamin called the 'logic of the new' per se, I see no reason why such a perspective should be at odds with the transcendental, future-opening historicity on which Derrida insists.

It becomes clear, then, that the various metaphysical foundations of democracy attempted to capture and justify what seems not altogether dispensable to democratic practices: the normativity of popular sovereignty, equal liberty, and human rights (among other things). Modernity is not only an invalidation of the normative content of tradition and religion, and an affirmation of the open-endedness of the future, but must also be viewed as an attempt to translate and reformulate those normative contents. These translations and reformulations have made their way into the concept of democracy Derrida wishes to inherit. Such an inheritance must, I believe, capture and negotiate these normative contents. Precisely insofar as Derrida's futural historicity insists, against much of modernity's self-understanding, on the complex inseparability of tradition and religion, on the one hand, and the affirmation of the future, on the other, a fuller genealogical account of the inherited normative contents is indispensable. Derrida is correct to point out that such negotiation does well to reflect on the conditions of historicity under which it operates, for such conditions provide both its space of possibility and the aporias and demands to be negotiated. In other words, they make democratic negotiations possible and render their harmonious and final solution impossible - in favor of the invention of new norms in singular circumstances. In this sense, futural openness may function as a transcendental 'metanorm' that subjects all normative accounts of democracy to perpetual revision and contestability from the viewpoint of elusive singularity, in the interest of reducing the violence that might otherwise result from such accounts. However, the specification of democracy's conditions of 
possibility will be one-sided if it leaves out the normativity that still calls for explication,

especially the values, such as equality, that Derrida recognizes but does not elaborate. ${ }^{64}$ Whether

such normativity requires an extra-political or a universal foundation in order to be furthered in

the 'unfinished project of modernity' has, I believe, been rendered doubtful by the Derridian

understanding of futural historicity, but it remains equally doubtful that this "other historicity"

[une autre historicité $]^{65}$ is sufficient to reformulate democracy in its plural and perhaps

contradictory normativity.

\section{NOTES}

\footnotetext{
${ }^{1}$ R. Rorty, Contingency, Irony, Solidarity (Cambridge: Cambridge University Press, 1989).

${ }^{2}$ Derrida, The Other Heading: Reflections on Today's Europe, tr. P.-A. Brault and M. Naas (Bloomington: Indiana University Press, 1992), 78.

${ }^{3}$ Derrida, Specters of Marx, tr. P. Kamuf (London: Routledge, 1994), 105/173. The difficulty here lies in thinking what Derrida, following Husserl, has called a "transcendental historicity" (Derrida, Writing and Difference, tr. A. Bass (Chicago: University of Chicago Press, 1978), 316fn46; Derrida, Edmund Husserl's Origin of Geometry, tr. J.P. Leavey, Jr. (Lincoln: University of Nebraska Press, 1989), 75), or, for short, the 'quasi-transcendental.' For an analysis of the quasi-transcendental, see, among others: R. Gasché, The Tain of the Mirror: Derrida and the Philosophy of Reflection (Cambridge, MA: Harvard University Press, 1986), 316ff; J.D. Caputo, 'On not Circumventing the Quasi-Transcendental: The Case of Rorty and Derrida' in G.B. Madison, ed., Working Through Derrida (Evanston: Northwestern University Press, 1993); G. Bennington and Derrida, Jacques Derrida (Chicago: University of Chicago Press, 1993), 267ff; M. Hobson, Jacques Derrida: Opening Lines (London: Routledge, 1998), ch. 1, 'History and Transcendentals.'

${ }^{4}$ Derrida, The Politics of Friendship, tr. G. Collins (London: Verso, 1997), 306.

${ }^{5}$ Derrida, "Force of Law: The "mystical foundation of authority"' in Drucilla Cornell et al., eds., Deconstruction and the Possibility of Justice (London: Routledge, 1992).

${ }^{6}$ Derrida, Specters of Marx, 56-70, esp. 63.

${ }^{7}$ Derrida, "Politics and Friendship," 5.

${ }^{8}$ Derrida, Politics of Friendship, 105.

${ }^{9}$ Ibid, passim.

${ }^{10}$ Ibid., 104.

${ }^{11}$ Cf. Derrida, On the Name, tr. D. Wood et al. (Stanford: Stanford University Press, 1995), $28 \mathrm{ff}$.

${ }^{12}$ Derrida, The Other Heading, 54f.

${ }^{13}$ Derrida, "Performative Powerlessness: A Response to Simon Critchley," Constellations 7, no. 4 (2000): 467. I say 'a bit hastily' because I think that Derrida, on numerous occasions, construes the opposition between norms and genuine decisions, between protocols and free outcomes, between a pre-programmed machine and undecidability, too strongly. For Derrida, undecidability is the condition of possibility of every genuine decision because without it, the decision would be a mere 'program' (for example, Derrida, "Hospitality, Justice and Responsibility: a Dialogue with Jacques Derrida" in Questioning Ethics: Contemporary Debates in Philosophy, ed. R. Kearney, M. Dooley (London: Routledge, 1999), 66). As Derrida argues, however, if all such programs and machines remain, as they must, subject to the repetition from an open future, undecidability and the possibility of the new and unforeseen is always given. The idea of a machine-run program that makes political decisions is a mere thought-experiment, as is the home without at least some degree of hospitality, the house without windows or doors (cf. Derrida, "Foreigner
} 
Question" in J. Derrida and A. Dufourmantelle, Of Hospitality, tr. R. Bowlby (Stanford: Stanford University Press, 2000), 61). For this reason alone, discursive norms, especially if they are procedural in design, do not - because they cannot - rule out otherness, novelty, undecidability, and responsibility. In no way is discourse ethics committed to assert that its transcendental-pragmatic norms pre-program decisions. Thus, Derrida's claim that, "There is no more responsibility when there are norms" ("Performative Powerlessness," 467), is misleading, even if we concede that ethics might require the excess of a gift beyond the limit specified by norms. This is not to say, of course, that Habermas's and Apel's norms of argumentative speech do not privilege a certain model of language.

${ }^{14}$ But also in contradistinction to the logic of modern totalitarianism. Already in the early 1980s, Philippe LacoueLabarthe and Jean-Luc Nancy organized a conference devoted to Derrida's work in which they (in Derrida's presence) presented Claude Lefort's analysis of twentieth-century European totalitarianism as a response to "democracy in crisis." See Lacoue-Labarthe and Nancy, Retreating the Political, tr. Simon Sparks (London: Routledge, 1997), 127ff. According to this analysis of modern democracy, the very site of power has become empty, as opposed to its former embodiment by the person of a prince, justified by reference to extra-political, usually theological or mythical instances. Democracy must do without a transcendent guarantor of order and unity (such as the nation), and without a center of organization, its references to unity must be wholly internal to itself (thus collapsing the distinction between internal and external). Since power, knowledge, and the law are not founded on assured, extra-political grounds, the possibility is opened up of an unending process of questioning, a questioning even of supposedly scientific truth.

${ }^{15} \mathrm{Cf}$. Derrida, Politics of Friendship.

${ }^{16} \mathrm{Cf}$. Bennington, Interrupting Derrida, chs. 2 and 3.

${ }^{17}$ Derrida, Specters of Marx, 16.

${ }_{18}^{18}$ Derrida, Politics of Friendship, 22.

19 "The affirmation of the future to come: this is not a positive thesis. It is nothing other than affirmation itself, the 'yes' insofar as it is the condition of all promises and of all hope, of all awaiting, of all performativity, of all opening toward the future, whatever it may be...." Derrida, Archive Fever. A Freudian Impression, tr. E. Prenowitz

(Chicago: University of Chicago Press, 1996), 68.

${ }^{20}$ E.g., Derrida, "Force of Law," 28.

${ }^{21}$ Derrida, "Foreigner Question," 75, 81. Derrida says that he keeps the Kantian name "categorical imperative" only "under erasure" (83), for a deconstructed duty must be a duty without duty: if duty is fulfilled because it is one's duty, it is not graciously offered, it is no pure gift beyond debt, and leaves little space for invention. This is another reason why Derrida is not interested in legitimating and founding democratic practices with absolute necessity.

${ }^{22}$ Derrida, "The Deconstruction of Actuality," Radical Philosophy 68 (1994): 32.

${ }^{23}$ M. Nussbaum, "Aristotle on Human Nature and the Foundation of Ethics" in: J.E.J. Altham, R. Harrison (eds.) World, Mind, and Ethics. Essays on the Ethical Philosophy of Bernard Williams (Cambridge: Cambridge University Press); A. Gewirth, Reason and Morality (Chicago: University of Chicago Press, 1978); K.-O. Apel, "Das Problem der philosophischen Letztbegründung im Lichte einer transzendentalen Sprachpragmatik," Sprache und Erkenntnis, ed. B. Kanitschneider (Innsbruck, 1976); J. Habermas, "Diskursethik: Notizen zu einem Begründungsprogramm," Moralbewußtsein und kommunikatives Handeln (Frankfurt: Suhrkamp, 1983).

${ }^{24}$ Cf. M. Jay, "The Debate over Performative Contradiction: Habermas versus the Poststructuralists" in A. Honneth et al., eds., Philosophical Interventions in the Unfinished Project of Enlightenment (Cambridge, MA: MIT Press, 1992), 267ff.

${ }^{25}$ Derrida thinks we cannot think this co(i)mplication of identity and difference other than as contradictory, so that an inevitable negativity enters our concepts. For an attempt to avoid this conclusion in a pragmatist, roughly

Habermasian manner, see Christoph Menke, Die Souveränität der Kunst. Ästhetische Erfahrung nach Adorno und Derrida (Frankfurt: Suhrkamp, 1991), 217ff.

${ }^{26}$ Derrida, Writing and Difference, 91.

${ }^{27}$ Derrida, Specters of Marx, 65.

${ }^{28}$ Derrida, "Foreigner Question," 25.

${ }^{29}$ Ibid., 149; cf. Derrida, Adieu to Emmanuel Levinas, tr. P.-A. Brault and M. Naas (Stanford: Stanford University Press, 1999), 33.

${ }^{30}$ Derrida, "Foreigner Question," 53.

${ }^{31}$ Ibid., 55, 59.

${ }^{32}$ Ibid., 147.

${ }^{33}$ Ibid., 65. 
${ }^{34}$ Derrida, Specters of Marx, 16; Derrida, "Living On: Borderlines" in Harold Bloom et al., eds., Deconstruction and Criticism (New York: Seabury, 1979), passim.

${ }^{35}$ Derrida, Specters of Marx, 169.

${ }^{36}$ Ibid., 65; cf. Derrida, "The Force of Law."

${ }^{37}$ Derrida, Politics of Friendship, 22.

${ }^{38}$ Derrida, Archive Fever, 68.

${ }^{39}$ Derrida, Of Spirit, tr. Geoffrey Bennington and Rachel Bowlby (Chicago: University of Chicago Press, 1989), 132f; cf. M. Heidegger, "Vom Wesen der Sprache," Unterwegs zur Sprache (Pfullingen: Neske, 1986), 175.

${ }^{40}$ E. Laclau and C. Mouffe, Hegemony and Socialist Strategy. Towards a Radical Democratic Politics (London: Verso, 1985); C. Mouffe, The Democratic Paradox (London: Verso, 2000).

${ }^{41}$ Cf. J.-L. Nancy, The Inoperative Community, tr. P.Connor et.al. (Minneapolis: University of Minnesota Press, 1991); Mouffe, The Democratic Paradox.

${ }^{42}$ Cf. Derrida, Politics of Friendship, 22.

${ }^{43}$ Derrida, Writing and Difference, 313.

${ }^{44} \mathrm{Cf}$. Derrida, Specters of Marx, $174 \mathrm{f}$.

${ }^{45}$ E.g., Bennington, Interrupting Derrida; R. Beardsworth, Derrida and the Political (London: Routledge, 1996).

${ }^{46}$ By using this term, I do not mean to imply that Derrida's ethics of openness, especially in its Levinasian inspiration, neglects moral intentions and moral character. Nor do I mean to associate Derrida with any known versions of a consequentialist ethics, such as utilitarianism, though it might be productive to compare this understanding of Derrida to such versions, and to ask, for example, if a rule-consequentialism would not be required here: if violence is to be reduced, what (democratic) laws and institutional structures achieve this goal best? Given the well-known problems of many consequentialisms, such as its orientation of desire to a single goal, we may also ask whether violence can be both defined so comprehensively as to cover all ethical cases, while still being measurable.

${ }^{47}$ Derrida, "Discussion with Richard Kearney" in J.D. Caputo and M.J. Scanlon, eds., God, Gift, and Postmodernism (Bloomington: Indiana University Press, 1999), 133. In other contexts, Derrida explicitly denies that hospitality is "an idea in the Kantian sense"; see, e.g., Derrida "Ich mißtraue der Utopie - ich will das UnMögliche," Die Zeit, 5 March 1998, 49.

${ }^{48}$ Derrida, "Foreigner Question," 27.

${ }^{49}$ Derrida, "Ich mißtraue der Utopie," 48.

${ }^{50}$ Ibid.

${ }^{51}$ Bennington, Interrupting Derrida, 28, 201, cf. 36.

${ }_{53}^{52}$ Derrida, "Foreigner Question," 149.

${ }^{53}$ If the argument on the basis of the reduction of violence can be fleshed out satisfactorily, I cannot agree with Ernesto Laclau's claim, in an otherwise very perceptive account, that no relation between Derrida's quasitranscendental and normative claims can be established. To reveal the extent of the problem, Laclau suggests that one might even try to justify totalitarianism on deconstructionist premises: precisely because of the inherent lack of closure in political organizations, as demonstrated by deconstruction, such closure and order, one might argue, has to be brought in artificially from the outside. E. Laclau, Emancipation(s) (London: Verso, 1996), $77 \mathrm{f}$.

${ }^{54} \mathrm{Cf}$. Beardsworth, Derrida and the Political, $46 \mathrm{ff}$.

${ }^{55}$ Derrida and B. Stiegler, Echographies de la télevision. Entretiens filmés (Paris: Galilée, 1996), 95ff.; Derrida, "Ich mißtraue der Utopie," 48.

${ }^{56}$ Derrida and B. Stiegler, Echographies de la television, 98.

${ }^{57}$ In this context, we should also consider that Derrida, as is clear from some of his oral remarks, welcomes some of the 'deconstructive effects' of capitalism - for example, the undermining the 'phallogocentric' concept of democratic fraternity and filiation (cf. Derrida, "Politics and Friendship," 11). This raises the crucial question - a question I cannot discuss here - as to the connection between the deconstruction of phallogocentrism and postFordist markets. In turn, the historical status of the quasi-transcendental conditions deconstruction wishes to expose is complicated. That Derrida recognizes the permissibility of such inquiries into the historical, socio-economic conditions of the quasi-transcendental arguments deconstructive thought advances becomes clear, for example, when he points out that the "historicity of history" must take into account the "history of historicity" (Derrida, "Faith and Knowledge" in Derrida and G. Vattimo, ed., Religion (Stanford: Stanford University Press, 1998b), 9). See also note 3 for more literature on the relation between quasi-transcendental concepts and history.

${ }^{58}$ Ibid., 96. 
${ }^{59}$ Derrida, Specters of Marx, $102 \mathrm{ff}$.

${ }^{60}$ As I pointed out above, Derrida is, of course, aware that respect for otherness and plurality must mean - at the political and even, pace Levinas, at the ethical level of the face-to-face - equal respect (cf. Derrida, Adieu to Emmanuel Levinas). This is what leads him to highlight the inescapable aporia of singularity and equality that all democratic legislation and law enforcement have to negotiate. There should also be no doubt that Derrida is concerned with the inequalities and the "excluded victims" of " "globalization' or mondialisation," although one might doubt whether 'exclusion' is the primary problem in this regard (Derrida, Without Alibi, tr. Peggy Kamuf (Stanford: Stanford University Press, 2002), 227; cf. Derrida, "Interview with Richard Beardsworth: Nietzsche and the Machine" Journal of Nietzsche Studies 7 (1994): 7-66). At the conceptual level, however, Derrida, while calling for the invention of new rules in particular situations to mitigate the unavoidable violence this aporia necessitates, appears to prioritize not only the singularity of the situation in which such aporetic negotiation is to take place, but the personal other's singularity as well as the pluralization and alterity that are associated with the repetition from the future to come. At this level, Derrida appears to lack a corresponding interest to conceptualize equality.

${ }^{61}$ Cf. W.E. Connolly, The Ethos of Pluralization (Minneapolis: University of Minnesota Press, 1995), 80ff.

${ }^{62}$ The problem of an insufficient (quasi-)ontological theory to suggest, and account for, 'emancipatory' or 'progressive' moral and political affirmations, especially the ideal of pluralization, is a quite notorious one in 'poststructuralist' thought. See, for instance, Stephen White's critique of Connolly's affirmation of 'critical responsiveness' and openness to plurality on the basis of a (Nietzschean and Foucaultian) abundance of vital being. White argues that on such a basis, we might also justify political repression rather than equality and pluralization, for repression may generate experiental richness. S.K. White, Sustaining Affirmation. The Strengths of Weak Ontology in Political Theory (Princeton: Princeton University Press, 2000), 127 ff.

${ }^{63}$ Derrida and B. Stiegler, Echographies de la television; Beardsworth, "Towards a Critical Culture of the Image," Tekhnema 4 (Spring 1998).

${ }^{64}$ The need for a richer genealogical perspective arises also from the notorious problem of distinguishing necessary from unnecessary violence (though this might be done only within specific situations), and of defining violence in such a way as to allow its measuring. I cannot here discuss and evaluate, with this normative question in mind, Derrida's attempts, in Of Grammatology (tr. Gayatri Spivak, (Baltimore: Johns Hopkins University Press, 1976), $112 \mathrm{ff}$.), to distinguish three levels of violence. But it should be clear that the notion of violence cannot determine with ease which inherited, democratic values are to be preferred over others, for what counts as violence can hardly be decided without such values.

${ }^{65}$ Derrida, Specters of Marx, 74f. 